Article

\title{
Plain and Ultrafine Fly Ashes Mortars for Environmentally Friendly Construction Materials
}

\author{
Luigi Coppola ${ }^{1,2}$ (D), Denny Coffetti ${ }^{1,2, *(1)}$ and Elena Crotti ${ }^{1,2}$ (I) \\ 1 Department of Engineering and Applied Sciences, University of Bergamo, 24129 Bergamo, Italy; \\ luigi.coppola@unibg.it (L.C.); elena.crotti@unibg.it (E.C.) \\ 2 Consorzio INSTM, UdR “Materials and Corrosion", 50121 Florence, Italy \\ * Correspondence: denny.coffetti@unibg.it; Tel.: +39-035-205-2030
}

Received: 8 January 2018; Accepted: 17 March 2018; Published: 19 March 2018

\begin{abstract}
This paper is aimed to study the rheological and physical performance of mortars manufactured replacing Portland-based cements with low calcium siliceous fly ash (FA) or ultrafine fly ash (UFFA). Five different types of cement (CEM I, CEM II / A-LL, CEM III/A, CEM III/B, and CEM IV according to EN 197-1) were used. Mortars were manufactured with FA or UFFA replacing 5\%, $15 \%, 25 \%, 35 \%$, and $50 \%$ of cement mass. Results indicate that compressive strength of mortars with UFFA is considerably higher than that of mixtures containing traditional FA, both at early and long ages. Moreover, experimental data reveal that replacement of cement with up to $25 \%$ of UFFA determines higher compressive strength at 7, 28, and 84 days than plain mortars (containing cement only), regardless of the type of cement used. Mortars manufactured with $35 \%$ or $50 \%$ of UFFA show slightly lower or similar compressive strength compared to the reference mortar (containing cement only). In addition, the results show values of the strength activity index of mortars made with FA $25 \%$, $23 \%$, and $20 \%$ lower than the reference corresponding mortars (cement only) at 7,28 , and 84 days, respectively. The grinding of FA, despite resulting in an increase in production energy and $\mathrm{CO}_{2}$ emissions compared to unmilled FA, allows a wide use of these SCM (Supplementary Cementitious Materials) in place of cement, reducing the environmental impact of mortars up to $40 \%$ at the 28-day strength class. The use of UFFA ensures better resistance in $\mathrm{CaCl}_{2}$-rich environments.
\end{abstract}

Keywords: ultrafine fly ash; fly ash; high volume fly ash; replacement of Portland cement; sustainability

\section{Introduction}

Climate changes have emerged today as life-threatening issues for the whole world. The principal $\mathrm{CO}_{2}$-emitting sectors of the economy include coal-fired power plants, transportation, and major manufacturing construction industries such as steel and cement. In particular, the concrete industry impact on greenhouse gasses (GHG) emissions and non-renewable energy consumptions has been discussed in several publications [1,2]. According to Schneider et al. [1], annual global cement production has reached 2.8 billion tons, and it is expected to increase up to 4 billion tons per years in a decade. The gross energy requirement for Portland cement production ranges from $2900 \mathrm{MJ} /$ ton to $3300 \mathrm{MJ} /$ ton of clinker, and $\mathrm{CO}_{2}$ emissions are approximately equal to $0.90 \mathrm{ton} /$ ton of clinker [3]. For these reasons, the main challenge for the concrete industry in the future consists of finding the right tools to support the growth of the population —and the subsequent industrialization and urbanization-by protecting the environment [4-6] and, at the same time, reducing the consumption of energy $[7,8]$ and natural resources [9-12] .

The coal-fired power plants generate considerable solid wastes that included fly ash (FA) —up to 700 million tons per years worldwide - that can be used in cement and concrete production due to its pozzolanic characteristics [13-15]. This allows to reduce gross energy requirement (GER), $\mathrm{CO}_{2}$ 
emissions (Global Warming Potential: GWP), and consumption in natural resources, since FA can partially replace Portland cement in concrete and mortar production.

Several studies have been conducted on mortars and concretes where Ordinary Portland Cement (OPC) has been partially replaced with FA [16-21]. Unfortunately, the optimization of composition of high volume fly ash (HVFA) concretes is quite complex due to the variation of fineness, mineralogy, and chemical composition (alkalis, sulfates, lime, and organics) of fly ashes. In order to overcome these difficulties, the use of ultrafine fly ash (UFFA) has also been proposed by Jones et al. [22] and Yazici et al. [23]. Generally, ultrafine fly ash is produced from traditional (class F according to ASTM C618 [24] or type V according EN 197-1 [25] and EN 450-1 [26]) fly ash by grinding, reaching particle size ranging from $1 \mu \mathrm{m}$ to $5 \mu \mathrm{m}$. Yazici et al. [23] concluded that compressive and splitting tensile strength of UFFA-based concretes increased along UFFA fineness. Supit et al. [27] noted that use of UFFA up to $15 \%$ in respect to binder mass determines a great improvement on compressive strength of HVFA mortars, especially at early ages, due to the larger specific surface area of ultrafine fly ash that promotes an increase in the amount of fly ashes involved in the pozzolanic reaction, an acceleration of this mechanism, and an improvement of both the transition zone and the microstructures of the matrix, especially in terms of porosity [28]. The same authors [29] investigated durability issues of concretes manufactured with UFFA characterized by mean size particles equal to $3.4 \mu \mathrm{m}$. Experimental results indicated that chloride diffusion coefficient decreases up to $70 \%$ respect to the reference mixture made with FA. Moreover, concretes containing UFFA exhibited better corrosion resistance in terms of smaller measured corrosion currents when compared to OPC concretes. Finally, the sulfate resistance is strictly related to the fineness of the fly ash employed. The higher the specific surface of FA, the lower the expansion of mortars in magnesium-sulfate-rich environments [30,31].

In this paper, an experimental study was carried out to assess rheological, mechanical, and physical properties of mortars manufactured with traditional low calcium siliceous (class $\mathrm{F}$ according to ASTM C618 [24] or type V according to EN 197-1 [25] and EN 450-1 [26]) FA and UFFA as a partial replacement of five different types of cement at equal water-binder ratio.

\section{Materials}

Five different types of cement, according to EN 197-1 [25], chosen between those widely used in Italy were used (Table 1). In addition, a low calcium siliceous (class F according to ASTM C618 [24] or type $\mathrm{V}$ according to EN 450-1 [26]) fly ash and, by grinding the same FA, an ultrafine fly ash (UFFA) were employed. Raw materials were characterized by XRD analysis (Rietveld method), XRF analysis, laser granulometry, SEM observations, and thermogravimetric analysis. Environmental parameters GER (Gross Energy Requirement) and GWP (Global Warming Potential) of cements reported in Table 1 have been taken from the Ecoinvent 3.0 database.

Table 1. Properties of cements (according to EN 197-1).

\begin{tabular}{|c|c|c|c|c|c|c|c|}
\hline & Cement Type & $\begin{array}{c}\text { Clinker } \\
\text { Content (\%) }\end{array}$ & $\begin{array}{l}\text { Specific Surface } \\
\left(\mathrm{cm}^{2} / \mathrm{g}\right)\end{array}$ & $\begin{array}{l}\text { Specific Mass } \\
\left(\mathrm{Kg} / \mathrm{m}^{3}\right)\end{array}$ & $\begin{array}{c}\text { L.O.I. } \\
950^{\circ} \mathrm{C}(\%)\end{array}$ & $\begin{array}{c}\text { GER } \\
(\mathrm{MJ} / \mathrm{kg})\end{array}$ & $\begin{array}{c}\text { GWP } \\
\left(\mathrm{kg} \mathrm{CO}_{2} / \mathrm{kg}\right)\end{array}$ \\
\hline CEM I 42.5 R & Portland cement & $95-100$ & 3200 & 2900 & 1.1 & 5.50 & 0.98 \\
\hline $\begin{array}{l}\text { CEM II/A-LL } \\
42.5 \mathrm{R}\end{array}$ & $\begin{array}{c}\text { Portland- } \\
\text { limestone cement }\end{array}$ & $80-94$ & 3650 & 3000 & 4.0 & 3.60 & 0.88 \\
\hline $\begin{array}{l}\text { CEM III/A } \\
42.5 \mathrm{R}\end{array}$ & $\begin{array}{l}\text { Blast furnace } \\
\text { cement }\end{array}$ & $35-64$ & 3950 & 2900 & 1.4 & 3.31 & 0.34 \\
\hline $\begin{array}{c}\text { CEM III/B } \\
42.5 \text { N LH-SR }\end{array}$ & $\begin{array}{l}\text { Blast furnace } \\
\text { cement }\end{array}$ & $20-34$ & 4100 & 2900 & 1.5 & 2.15 & 0.27 \\
\hline $\begin{array}{l}\text { CEM IV / A-P } \\
42.5 \mathrm{R}\end{array}$ & $\begin{array}{c}\text { Pozzolanic } \\
\text { cement }\end{array}$ & $65-89$ & 4000 & 2800 & not available & 2.98 & 0.53 \\
\hline
\end{tabular}

XRF and XRD analysis shows that in terms of chemical nature and crystallinity, FA and UFFA (UFFA is obtained by grinding FA) are silico-alumina-based amorphous materials with small amounts of iron oxide and calcium oxide (Table 2, Figure 1). Laser granulometry analysis (Table 3) confirms 
for UFFA, as a consequence of the grinding process, a reduction of average particle size $(16.69 \mu \mathrm{m}$ and $11.29 \mu \mathrm{m}$ is the D50 for FA and UFFA, respectively) and an increase in the specific surface area (4500 $\mathrm{cm}^{2} / \mathrm{g}$ and $6800 \mathrm{~cm}^{2} / \mathrm{g}$ for FA and UFFA, respectively).

Table 2. Chemical analysis of fly ash (FA) and ultrafine fly ash (UFFA).

\begin{tabular}{cccccccc}
\hline & $\mathrm{SiO}_{\mathbf{2}}(\mathbf{\%})$ & $\mathrm{Al}_{\mathbf{2}} \mathrm{O}_{\mathbf{3}}(\mathbf{\%})$ & $\mathrm{Fe}_{\mathbf{2}} \mathbf{O}_{\mathbf{3}}(\%)$ & $\mathrm{CaO}(\%)$ & $\mathbf{M g O}(\%)$ & $\mathbf{N a}_{\mathbf{2}} \mathbf{O}(\%)$ & $\mathbf{K}_{\mathbf{2}} \mathbf{O}(\%)$ \\
\hline Fly ash & 53.87 & 24.18 & 5.11 & 7.04 & 1.35 & 0.63 & 2.16 \\
Ultrafine fly ash & 54.00 & 25.00 & 5.21 & 7.50 & 1.90 & 0.68 & 2.55 \\
\hline
\end{tabular}

Table 3. Properties of FA and UFFA.

\begin{tabular}{|c|c|c|c|c|}
\hline & $D_{50}(\mu \mathrm{m})$ & Specific Surface $\left(\mathrm{cm}^{2} / \mathrm{g}\right)$ & Specific Mass $\left(\mathrm{kg} / \mathrm{m}^{3}\right)$ & L.O.I. $950^{\circ} \mathrm{C}(\%)$ \\
\hline Fly ash & 16.69 & 4500 & 2200 & 2.98 \\
\hline Ultrafine fly ash & 11.29 & 6800 & 2200 & 3.01 \\
\hline
\end{tabular}

The grinding process requires lower energy than that needed for grinding Portland cement clinker, reaching values close to $0.10 \mathrm{MJ} / \mathrm{kg}$. Therefore, grinding UFFA determines an increase in both energy requirement and greenhouse gases emissions compared to the unmilled fly ash. However, despite the increase in GER and GWP $\left(\mathrm{CO}_{2}\right.$ emissions grow by $50 \%$, GER doubles) as a consequence of grinding, the environmental impact of UFFA is extremely lower than that deriving from Portland cement production (Table 4).

Table 4. Energy requirements and $\mathrm{CO}_{2}$ emissions of FA and UFFA compared to Portland cement [32,33].

\begin{tabular}{|c|c|c|c|c|c|c|}
\hline & \multicolumn{2}{|c|}{ Grinding } & \multicolumn{2}{|c|}{ Preheating and Kiln } & \multicolumn{2}{|c|}{ Total * } \\
\hline & $\begin{array}{c}\text { GHG } \\
\text { Emissions } \\
\left(\mathrm{kg} \mathrm{CO}_{2} / \mathrm{kg}\right)\end{array}$ & $\begin{array}{c}\text { Energy } \\
\text { Requirement } \\
\text { (MJ/kg) }\end{array}$ & $\begin{array}{c}\text { GHG } \\
\text { Emissions } \\
\left(\mathrm{kg} \mathrm{CO}_{2} / \mathrm{kg}\right)\end{array}$ & $\begin{array}{c}\text { Energy } \\
\text { Requirement } \\
\text { (MJ/kg) }\end{array}$ & $\begin{array}{c}\text { GHG } \\
\text { Emissions } \\
\left(\mathrm{kg} \mathrm{CO}_{2} / \mathrm{kg}\right)\end{array}$ & $\begin{array}{c}\text { Energy } \\
\text { Requirement } \\
\text { (MJ/kg) }\end{array}$ \\
\hline CEM I $42.5 \mathrm{R}$ & $9.06 \times 10^{-3}$ & $0.32-0.36$ & $9.7 \times 10^{-1}$ & 5.10 & $9.8 \times 10^{-1}$ & 5.50 \\
\hline FA & - & - & - & - & $5.3 \times 10^{-3}$ & 0.10 \\
\hline UFFA & $2.10 \times 10^{-3}$ & $0.09-0.11$ & - & - & $7.4 \times 10^{-3}$ & 0.20 \\
\hline
\end{tabular}

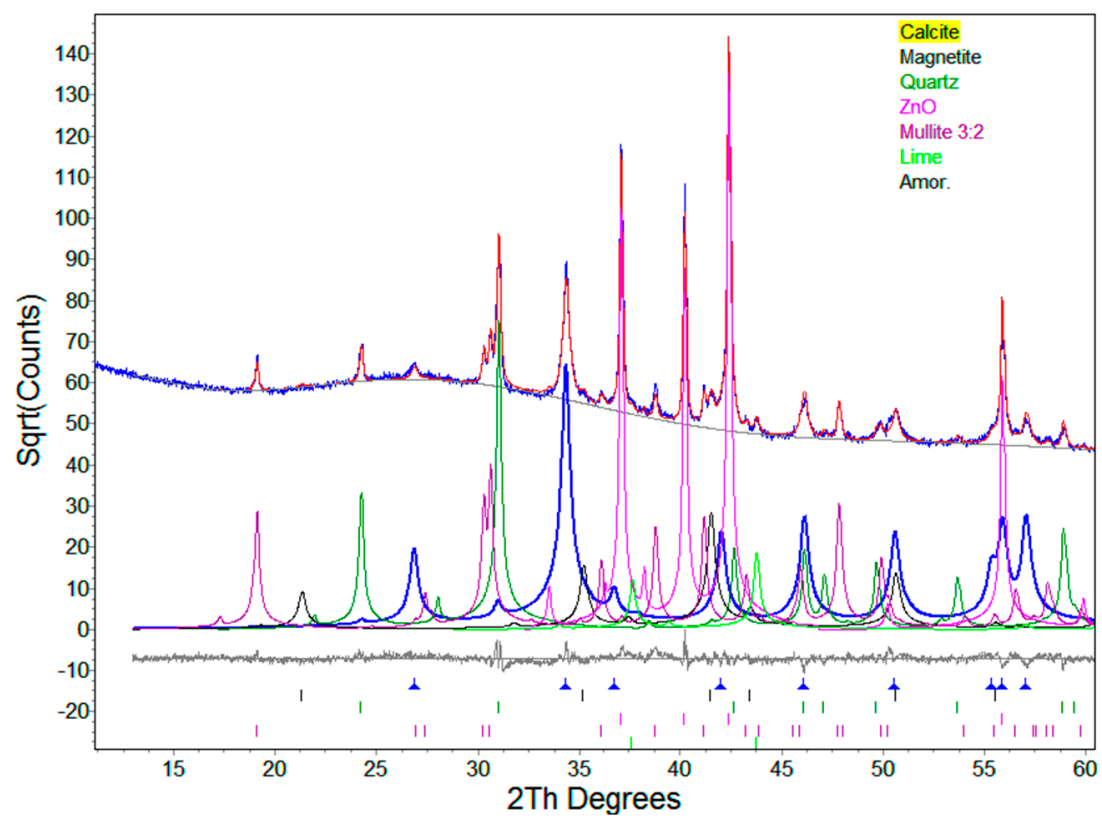

Figure 1. XRD analysis of ultrafine fly ash. 
SEM images show for UFFA the presence of uneven spheres of variable size, plenospheres, and irregular-shaped particles with net edges attributable to fragments of ground spheres (Figure 2). A comparison of Figure 2 (UFFA) and Figure 3 (which refers to not milled FA) indicates that the grinding process determines a general damage of particles, especially for those having a diameter greater than $50 \mu \mathrm{m}$. Thermogravimetric analysis evidences a weight loss of UFFA equal to $8.8 \%$ in the temperature range $250-1000{ }^{\circ} \mathrm{C}$ with a maximum of $850{ }^{\circ} \mathrm{C}$ and a sharp speed change at $800{ }^{\circ} \mathrm{C}$. Thermogravimetric measurements performed on FA (and UFFA) show an exothermic weight loss in the $600-800{ }^{\circ} \mathrm{C}$ temperature range. The $2.5 \%$ weight loss measured is in good agreement with LOI (Loss of Ignition) datum (2.98\% and 3.01\% for FA and UFFA, respectively).

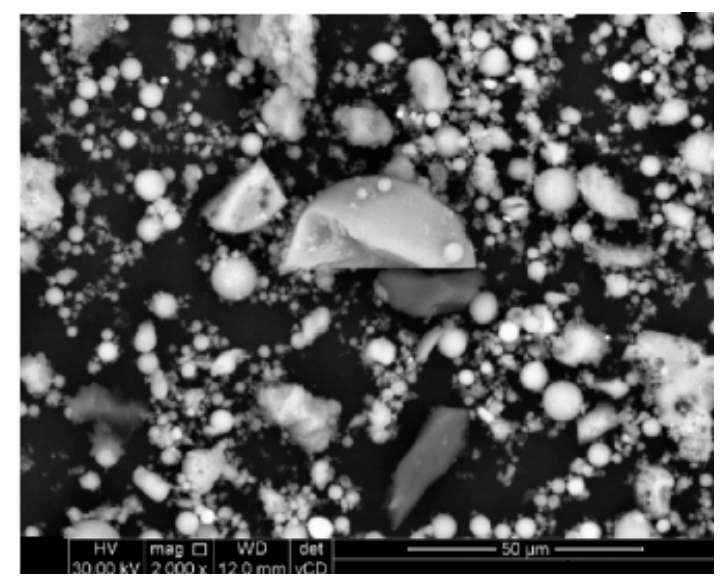

Figure 2. SEM image of ultrafine fly ash.

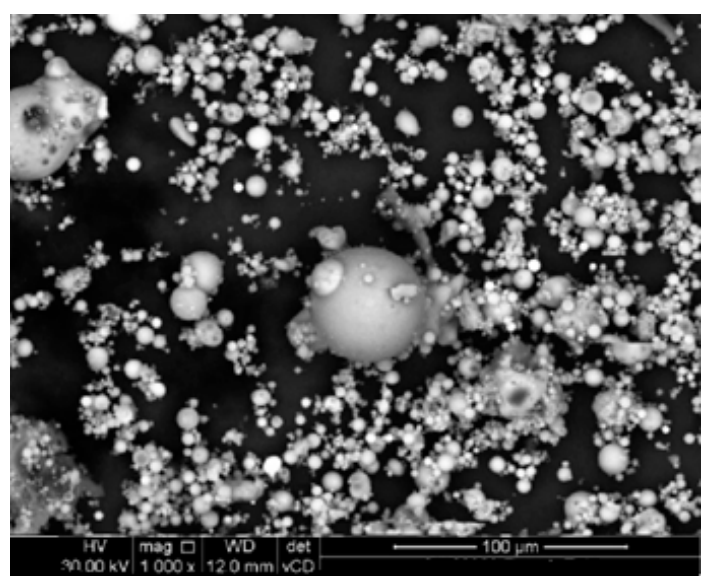

Figure 3. SEM image of fly ash.

\section{Experimental Procedure}

Fifty-five different types of mortars were manufactured with the same amount of water $\left(250 \mathrm{Kg} / \mathrm{m}^{3}\right)$ and the same cement or binder (cement + FA or UFFA) nominal content $\left(500 \mathrm{Kg} / \mathrm{m}^{3}\right)$ in order to keep constant the water-cement or water-binder ratio at 0.50 . Five reference mortars (without FA or UFFA) and 50 mixtures containing 5\%, 15\%, 25\%, 35\%, and 50\% by mass of FA or UFFA replacing cement were manufactured (Table 5). The sand-binder ratio of mortars was fixed equal to 3 (maximum diameter of natural siliceous aggregates equal to $2.5 \mathrm{~mm}$ ).

A chemical superplasticizer (ester of acrylic or methacrylic acid monomer) having $1000 \mathrm{~g} / \mathrm{mol}$ side chain length, and an acid-ester ratio equal to 3.5 was used to attain a suitable workability to place the mortars in moulds to manufacture $40 \times 40 \times 160 \mathrm{~mm}$ specimens. 
In order to evaluate the influence of the partial substitution of cement with FA or UFFA, several rheological and mechanical tests were carried out. Workability was measured by means of flow table according to EN 1015-3 [34]. In addition, the specific mass was evaluated on fresh mortars according to the EN 1015-6 standard [35]. Specific mass, compressive and flexural strength at 1, 7, 28, and 84 days ( $\mathrm{T}=20^{\circ} \mathrm{C}$, specimens soaked into water) were also determined on prismatic specimens according to EN 1015-11 [36] (four specimens for each mixture and age). Strength activity index (K: compressive strength of FA or UFFA mortar compared to that of the reference mortar containing cement only) was evaluated according to EN 450-1 [26] and Supit et al. [27] at different ages. The aim of the research is the evaluation of strength activity index of the most widely used cement in Europe in comparison to limits indicated by EN 206-1 [37]. In addition, drying shrinkage was measured over time on prismatic specimens (three specimens for each mixtures) stored in a climatic chamber at controlled temperature and humidity $\left(\mathrm{T}=20^{\circ} \mathrm{C}, \mathrm{R} . \mathrm{H} .=60 \%\right)$ according to EN 12617-4 [38]. Finally, durability tests were carried out on mortars. In particular, resistance of mortars to calcium chloride was investigated by placing 28-day-old prismatic specimens $\left(40 \times 40 \times 160 \mathrm{~mm}\right.$, ) in $30 \mathrm{wt} \% \mathrm{CaCl}_{2}$ solution for 28 days at $38^{\circ} \mathrm{C}$. Then, the specimens were maintained in the same solution at $4{ }^{\circ} \mathrm{C}$ in order to promote the calcium oxychloride formation. The compressive strength of mortars were evaluated over time (three specimens for each mixture and age). Lastly, tests on sodium chloride resistance, sulphate attack, and alkali-aggregate reaction were in progress.

\section{Results and Discussion}

\subsection{Rheological Properties}

Compositions and fresh properties of mortars are shown in Table 5. Replacement of Portland cement with FA or UFFA does not determine significant changes of the specific mass in the fresh state, regardless of the percentage of fly ash. On the contrary, the partial replacement of Portland with the FA determines an increase in the workability of the mortars, at the same amount of mixing water. Figure 4 shows a linear relationship between the workability and the percentage of FA replacing the cement, independently of the type of cement used. This behavior could be ascribed to the morphology of the fly ash, mainly of spherical shape (Figure 3), responsible for more fluid mixtures compared to reference mortar containing cement only. Grinding process, on the contrary, involves a general damage of particles, an increase in the number of irregular-shaped particles and a larger specific surface area responsible for a mitigation of the superplasticizing effect of UFFA compared to that shown by the (unground) fly ash (Figures 4 and 5).

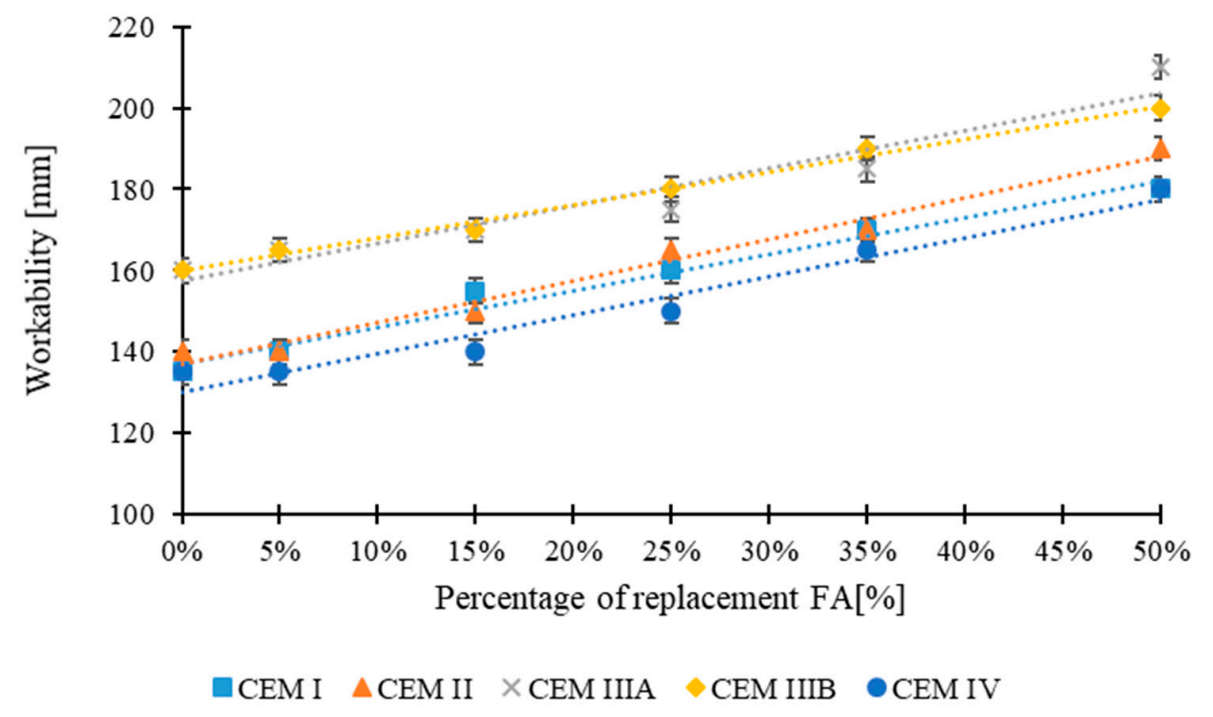

Figure 4. Workability by flow table of mortars vs. percentage of FA replacing cement. 


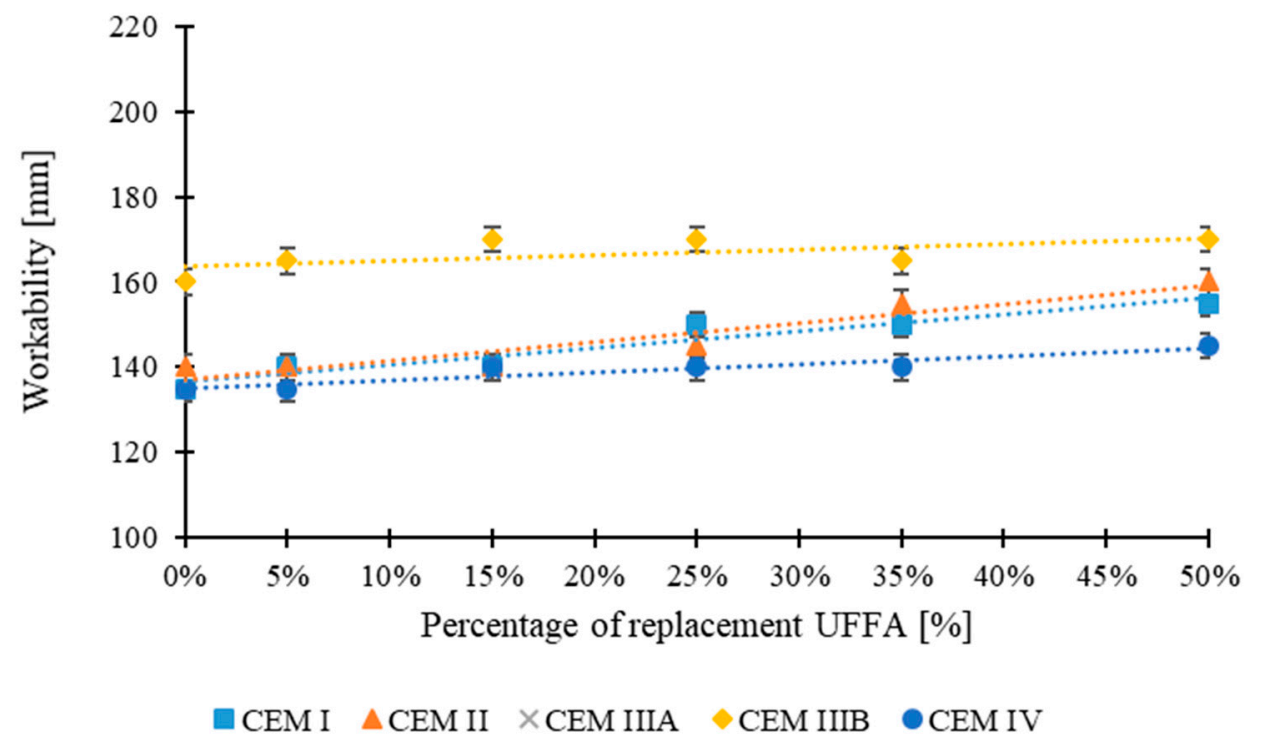

Figure 5. Workability by flow table of mortars vs. percentage of UFFA replacing cement.

Table 5. Composition of mortars.

\begin{tabular}{cccccccccccc}
\hline Composition & \multirow{2}{*}{ REF } & FA & FA & FA & FA & FA & UFFA & UFFA & UFFA & UFFA & UFFA \\
& & $\mathbf{5 \%}$ & $\mathbf{1 5 \%}$ & $\mathbf{2 5 \%}$ & $\mathbf{3 5 \%}$ & $\mathbf{5 0} \%$ & $\mathbf{5 \%}$ & $\mathbf{1 5 \%}$ & $\mathbf{2 5 \%}$ & $\mathbf{3 5 \%}$ & $\mathbf{5 0 \%}$ \\
\hline Cement $\left(\mathrm{kg} / \mathrm{m}^{3}\right)$ & 500 & 475 & 425 & 375 & 325 & 250 & 475 & 425 & 375 & 325 & 250 \\
Fly Ash $\left(\mathrm{kg} / \mathrm{m}^{3}\right)$ & $/$ & 25 & 75 & 125 & 175 & 250 & $/$ & $/$ & $/$ & $/$ & $/$ \\
$\quad \begin{array}{c}\text { Ultrafine fly ash } \\
\left(\mathrm{kg} / \mathrm{m}^{3}\right)\end{array}$ & $/$ & $/$ & $/$ & $/$ & $/$ & $/$ & 25 & 75 & 125 & 175 & 250 \\
Aggregates $\left(\mathrm{kg} / \mathrm{m}^{3}\right)$ & 1500 & 1500 & 1500 & 1500 & 1500 & 1500 & 1500 & 1500 & 1500 & 1500 & 1500 \\
$\quad$ Water $\left(\mathrm{kg} / \mathrm{m}^{3}\right)$ & 250 & 250 & 250 & 250 & 250 & 250 & 250 & 250 & 250 & 250 & 250 \\
Superplasticizer & 3.00 & 3.00 & 3.00 & 3.00 & 3.00 & 3.00 & 3.00 & 3.00 & 3.00 & 3.00 & 3.00 \\
$\quad\left(\mathrm{~kg} / \mathrm{m}^{3}\right)$ & 0.50 & 0.53 & 0.59 & 0.67 & 0.77 & 1.00 & 0.53 & 0.59 & 0.67 & 0.77 & 1.00 \\
w/c ratio * & 0.50 & 0.50 & 0.50 & 0.50 & 0.50 & 0.50 & 0.50 & 0.50 & 0.50 & 0.50 & 0.50 \\
w/b ratio ** & & &
\end{tabular}

* Water/cement by mass. ${ }^{* *}$ water/(cement + FA or UFFA) by mass.

\subsection{Mechanical Properties}

Compressive and flexural strength tests were carried out on prismatic specimens according to EN 1015-11 [36]. On the basis of compressive strength values, the strength pozzolanic activity index (K)-ratio of the compressive strength of mortar containing either UFFA or FA and the corresponding value of the reference mortar containing cement only, was calculated (Figures 6-15).

There is a general increase in the strength pozzolanic activity index using UFFA compared to the FA, regardless of the type of cement used and the percentage of replacement. In particular, the mixtures containing up to $25 \%$ of UFFA exhibited higher compressive strength at 7,28 , and 84 days than reference mortars (cement only), independently of the type of cement used. On the other hand, compressive strength at 7 and 28 days of mortars with 35\% of UFFA depends on the type of cement used. In fact, only mortars containing 35\% of UFFA manufactured with CEM I $42.5 \mathrm{R}$ and CEM II/ A-LL 42.5 R show a K-value higher than 1 (UFFA based mixtures compressive strength higher than that of the reference mortar). However, it can be observed that at 84 days, regardless of the type of cement used, the compressive strength of mortars containing 35\% of UFFA replacing cement is higher than that of mixtures manufactured exclusively with cement. Mortars manufactured with $50 \%$ of UFFA show values of $\mathrm{K}$ equal to 0.70 and 0.87 at 28 and 84 days, respectively. These data seem to indicate that reduction of clinker amount (as a consequence of the $50 \%$ cement replacement) inhibits the pozzolanic reaction and, hence, the compressive strength of the mortars [27]. Moreover, results show that replacement of cement with fly ash determines lower compressive strength of the mortar 
compared to the corresponding mixtures containing UFFA. In particular, the values of the strength pozzolanic activity index of mortars manufactured with fly ash are $25 \%, 23 \%$, and $20 \%$ lower at 7,28 , and 84 days, respectively.

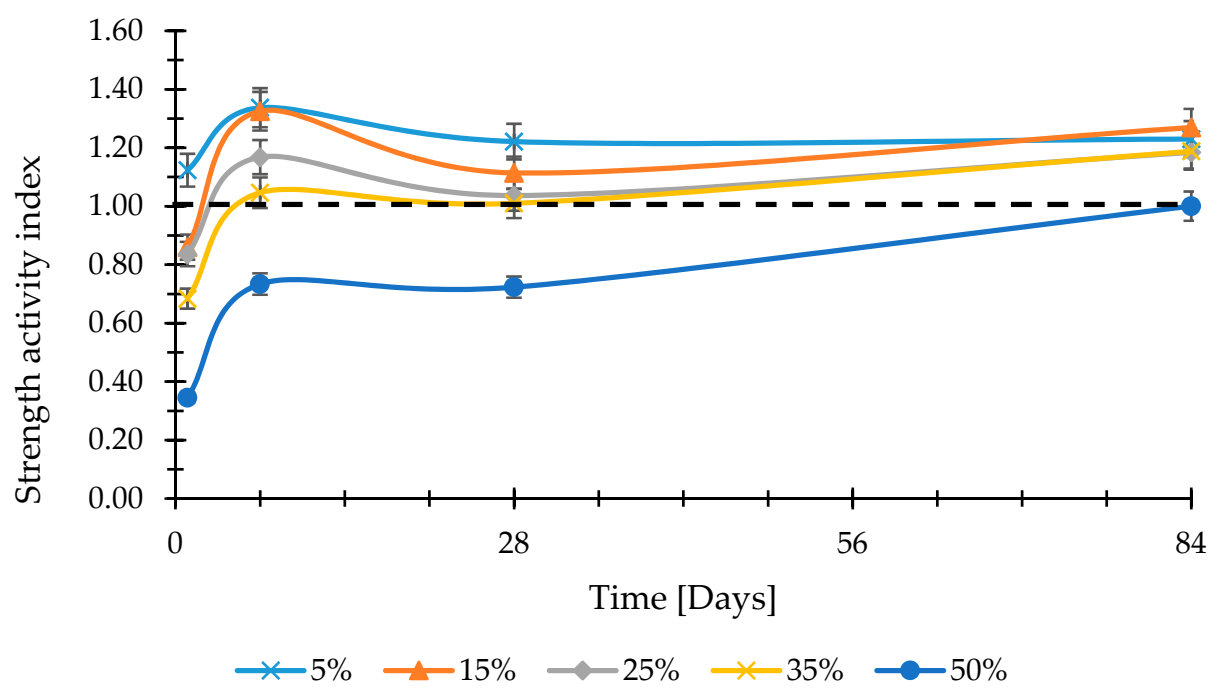

Figure 6. Strength activity index of mortars manufactured with CEM I and UFFA.

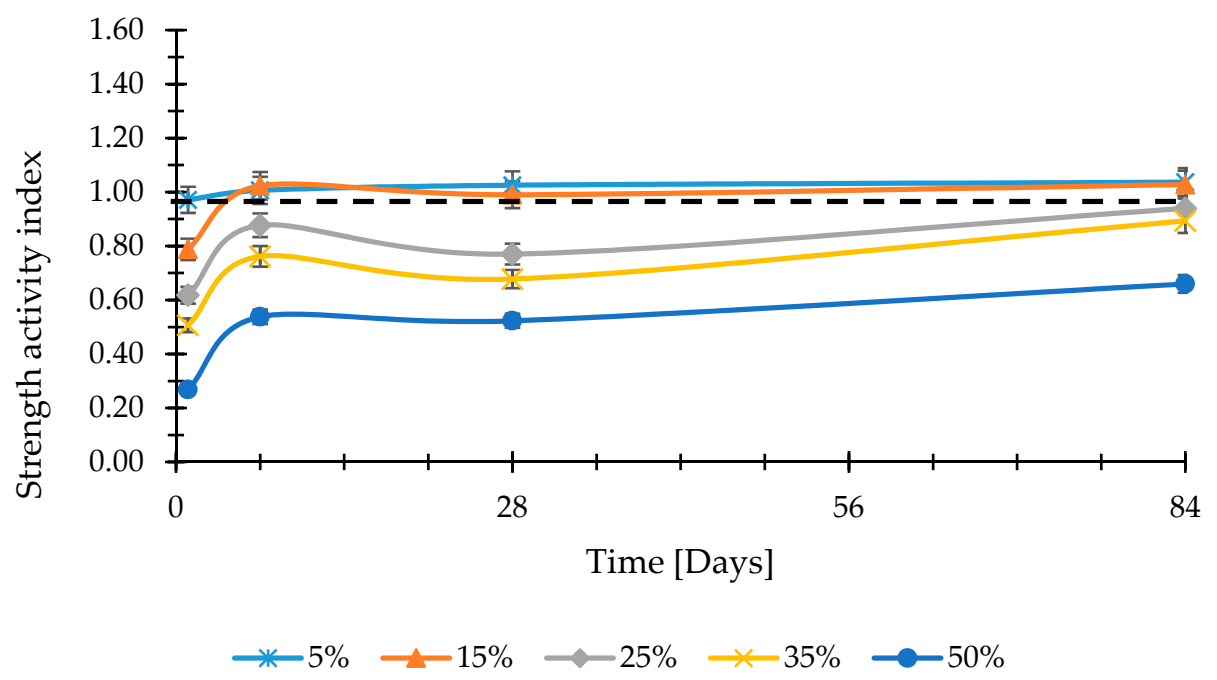

Figure 7. Strength activity index of mortars manufactured with CEM I and FA. 


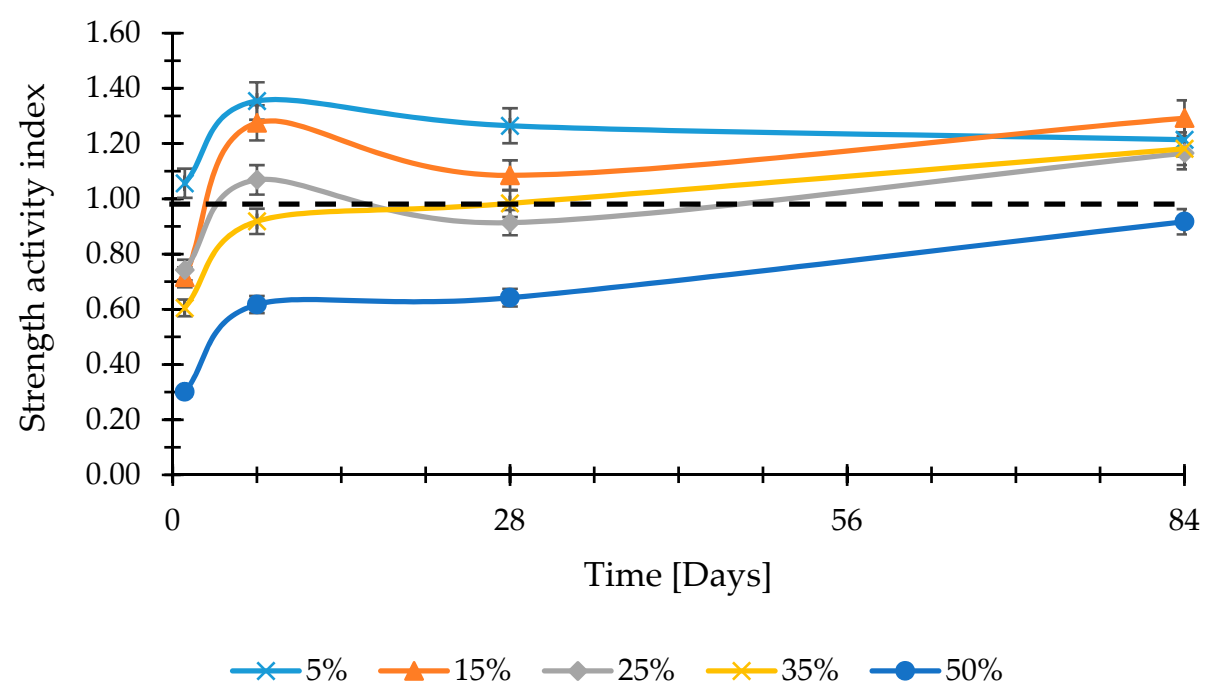

Figure 8. Strength activity index of mortars manufactured with CEM II/A-LL and UFFA.

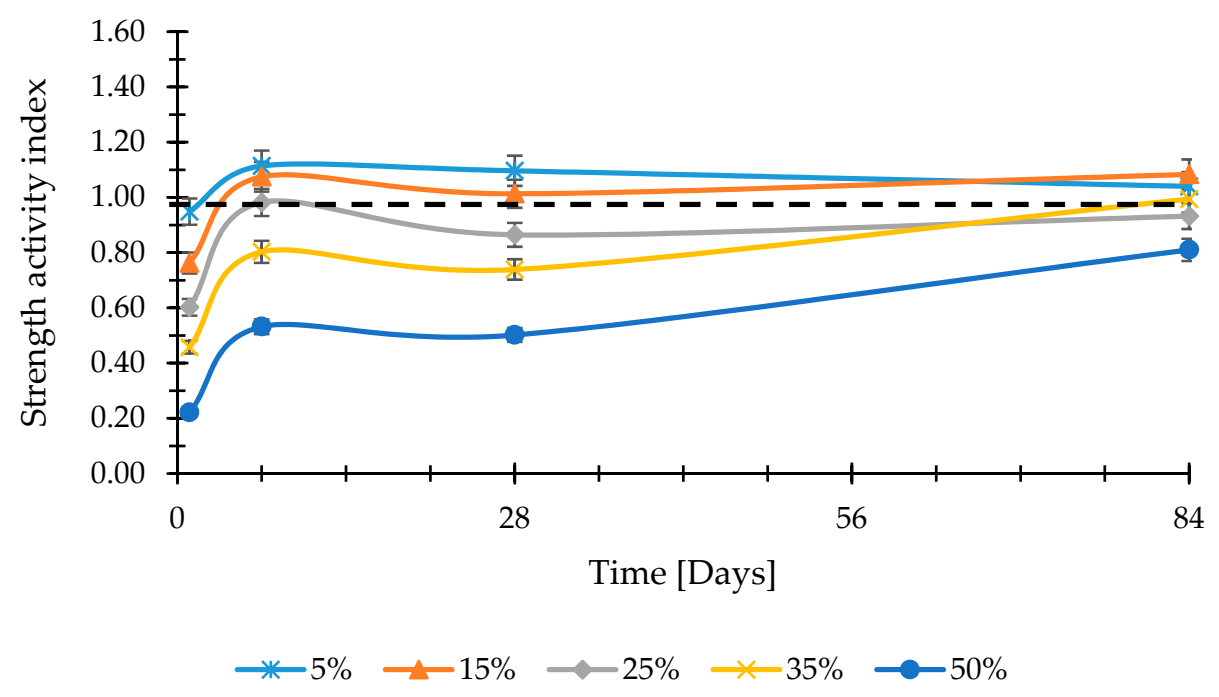

Figure 9. Strength activity index of mortars manufactured with CEM II/A-LL and FA.

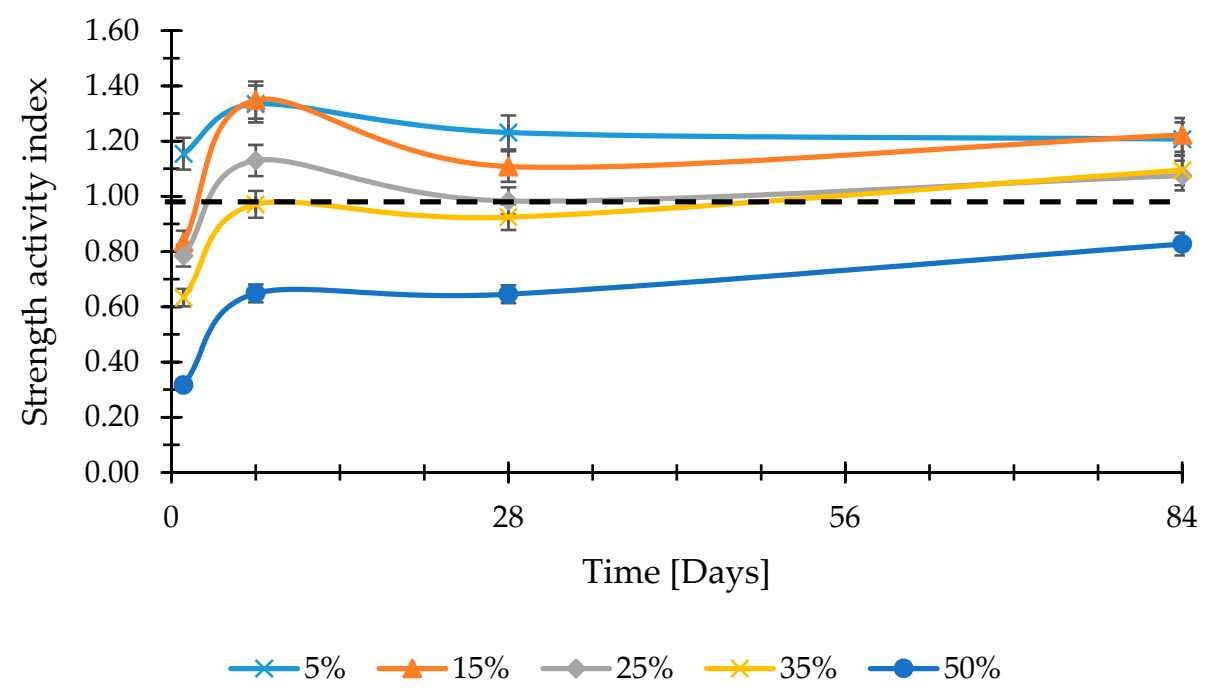

Figure 10. Strength activity index of mortars manufactured with CEM III/A and UFFA. 


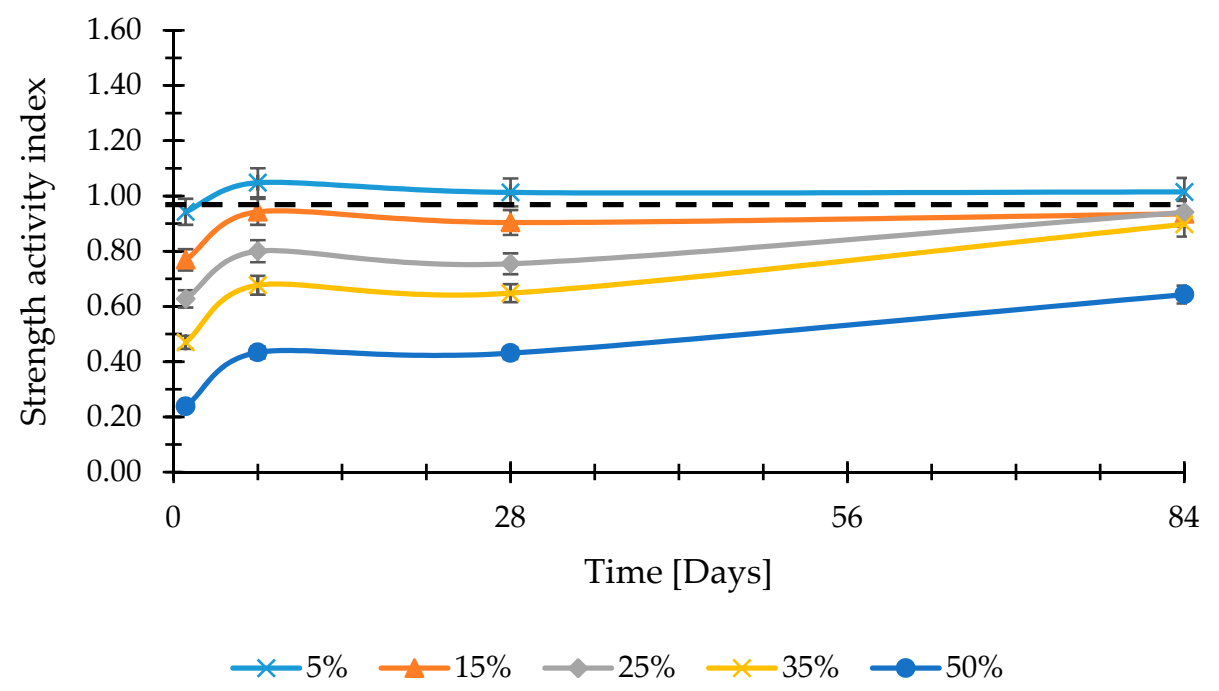

Figure 11. Strength activity index of mortars manufactured with CEM III/A and FA.

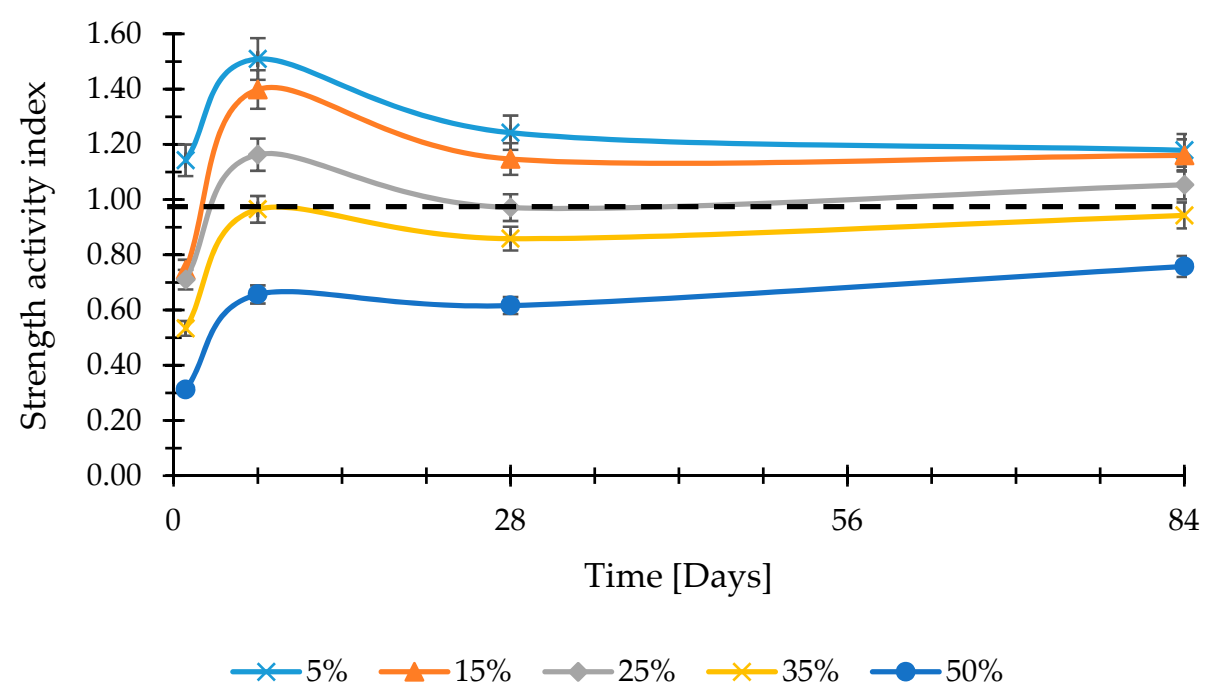

Figure 12. Strength activity index of mortars manufactured with CEM III/B and UFFA.

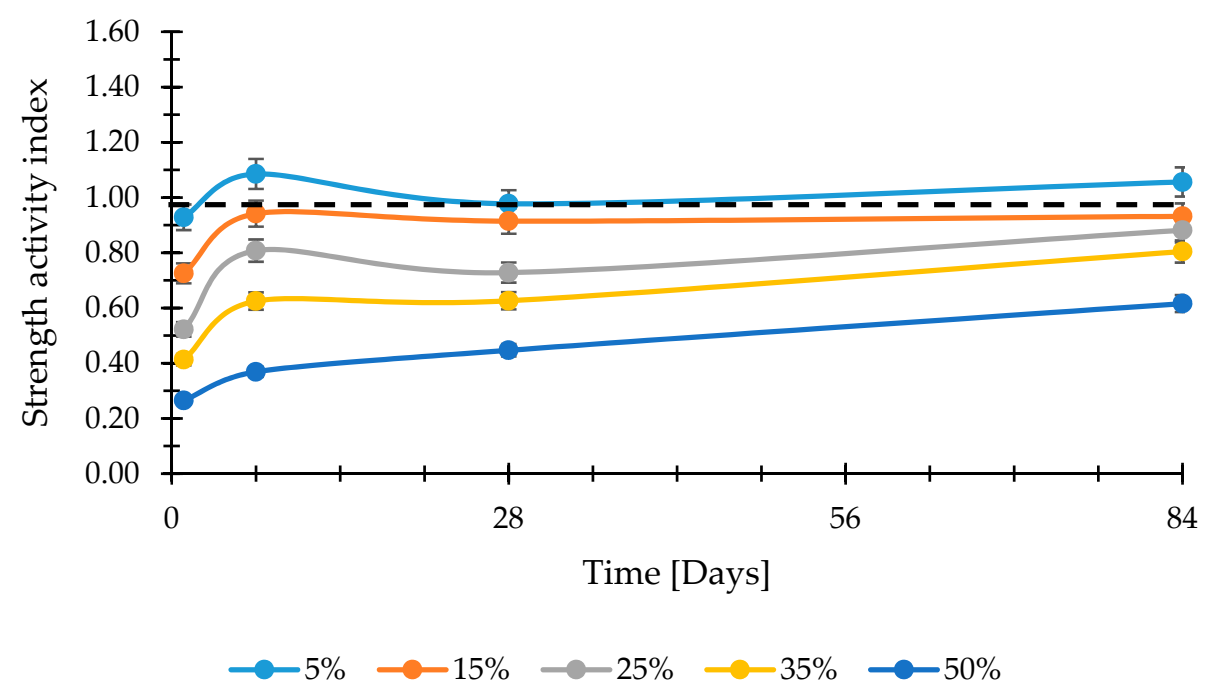

Figure 13. Strength activity index of mortars manufactured with CEM III/B and FA. 


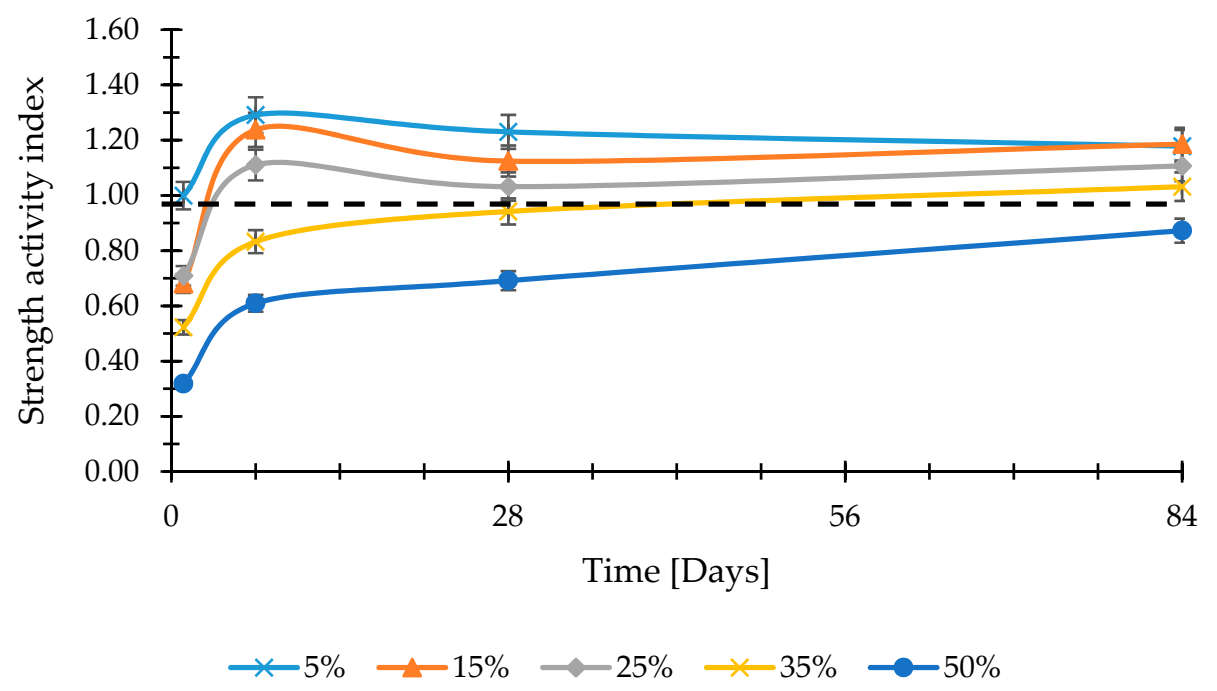

Figure 14. Strength activity index of mortars manufactured with CEM IV/A-P and UFFA.

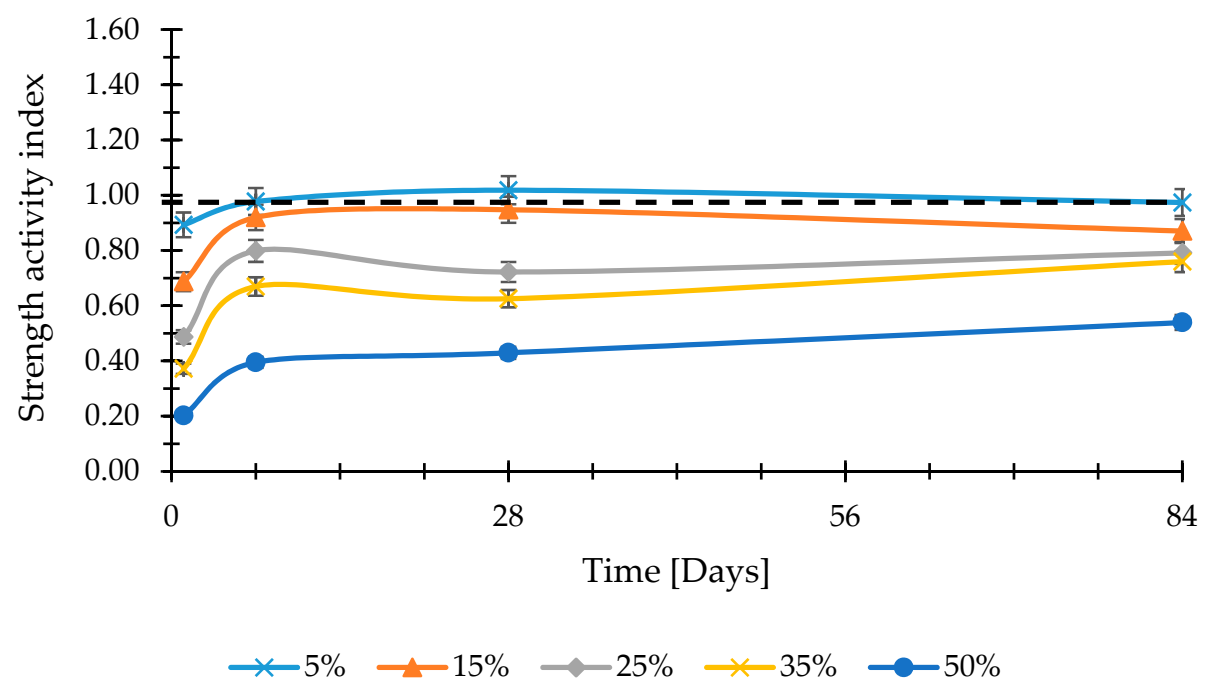

Figure 15. Strength activity index of mortars manufactured with CEM IV/A-P and FA.

\subsection{Shrinkage}

Shrinkage tests were performed up to 56 days on prismatic specimens at $20{ }^{\circ} \mathrm{C}$ and R.H. $60 \%$. The replacement of Portland cement with FA or UFFA does not determine significant changes in hydraulic shrinkage. In fact, regardless of the type of cement, a negligible reduction in shrinkage is observed as the percentage of replacement increases. The shrinkage values are similar to those of cement-based mortars. In particular, the average values are around 0.9-1.0 $\times 10^{-6}$ after 56 days from casting (Figure 16). It can therefore be concluded that UFFA and FA replacing cement do not lead to significant improvements in term of shrinkage, regardless of the type of cement used and the percentage of replacement. 


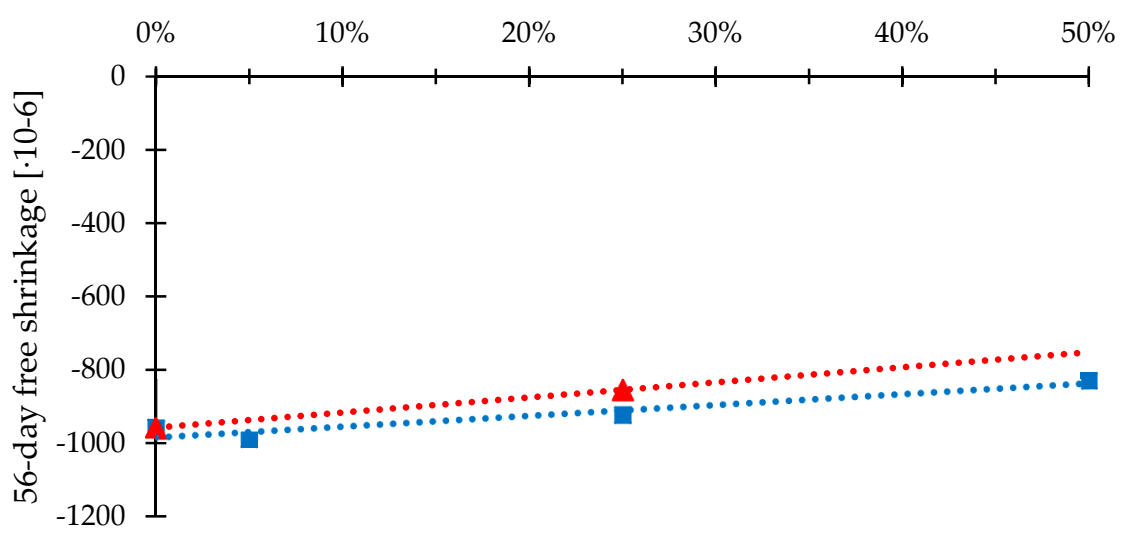

Percentage of replacement [\%]

- Ultrafine fly ash $\Delta$ Fly ash

Figure 16. Free shrinkage after 56 days of mortars vs. percentage of replacement.

\subsection{Sustainability Parameters}

In order to evaluate the effect of the partial replacement of cement with FA or UFFA on the sustainability of mortars, the environmental parameters GER and GWP of mortars manufactured with the five different cements were calculated. $\mathrm{CO}_{2}$ emissions and energy production of cement (Table 1), FA or UFFA (Table 4), and aggregates (GER: $0.13 \mathrm{MJ} / \mathrm{kg}$, GWP: $0.0024 \mathrm{~kg} \mathrm{CO}_{2} / \mathrm{kg}$ ) are reported. Calculation of GER and GWP has been performed for the reference mortars, FA and UFFA having the same 28-day compressing strength taken into account.

Table 6 show the percentage of FA and UFFA replacing the cement to achieve the same 28-day strength level. As clearly indicated, percentage of UFFA is higher than FA, independently of the cement. In mortars produced with CEM III/A, III/B, and IV A-P is possible to replace $25 \%$ of cement by UFFA and only $5 \%$ of FA. When CEM I and CEM II/A-LL are used, the amount of UFFA and FA replacing cement is $40 / 35 \%$ and $5 / 15 \%$, respectively. As a consequence of the higher amount of cement replaced by UFFA, the GWP of the mortar manufactured with the ultrafine fly ash is $35-40 \%$ lower with respect reference mortar (and about 20-35\% lower than the FA-based mortars having the same strength). At the same time, GER is reduced in UFFA-based mortars production of about $20-35 \%$ vs. reference mortar (and 15-30\% lower than the FA-based mortars having the same strength). Data clearly indicated that the higher energy (and $\mathrm{CO}_{2}$ emissions) required to ground the fly ash to produce UFFA is largely compensated by the strong reduction of GER and GWP in mortar production as a consequence of the higher K-index of UFFA vs. FA.

Table 6. Environmental parameters of mortars manufactured with UFFA or FA with respect to Portland cement-based mortars at the same 28-day strength class.

\begin{tabular}{|c|c|c|c|c|c|c|}
\hline & & Replacement (\%) & GER $\left(\mathrm{MJ} / \mathrm{m}^{3}\right)$ & GER (\% vs. REF) & $\mathrm{GWP}\left(\mathrm{kg} \mathrm{CO} \mathrm{Cm}_{2} / \mathrm{m}^{3}\right.$ & GWP (\% vs. REF) \\
\hline \multirow{3}{*}{ CEM I $42.5 \mathrm{R}$} & REF & - & 2945 & - & 494 & - \\
\hline & FA & $5 \%$ & 2810 & $95.4 \%$ & 469 & $94.9 \%$ \\
\hline & UFFA & $40 \%$ & 1885 & $64.0 \%$ & 299 & $60.5 \%$ \\
\hline \multirow{3}{*}{ CEM II/A-LL 42.5 R } & REF & - & 1995 & - & 444 & - \\
\hline & FA & $15 \%$ & 1733 & $86.9 \%$ & 378 & $85.1 \%$ \\
\hline & UFFA & $35 \%$ & 1400 & $70.0 \%$ & 291 & $65.5 \%$ \\
\hline \multirow{3}{*}{ CEM III/A 42.5 R } & REF & - & 1850 & - & 176 & - \\
\hline & FA & $5 \%$ & 1770 & $95.7 \%$ & 167 & $94.9 \%$ \\
\hline & UFFA & $25 \%$ & 1461 & $79.0 \%$ & 134 & $76.1 \%$ \\
\hline \multirow{3}{*}{ CEM III/B $42.5 \mathrm{~N}$} & REF & - & 1270 & - & 140 & - \\
\hline & FA & $5 \%$ & 1219 & $96.0 \%$ & 134 & $95.7 \%$ \\
\hline & UFFA & $25 \%$ & 1026 & $80.8 \%$ & 107 & $76.4 \%$ \\
\hline \multirow{3}{*}{ CEM IV/A-P 42.5 R } & REF & - & 1685 & - & 269 & - \\
\hline & FA & $5 \%$ & 1613 & $95.7 \%$ & 256 & $95.2 \%$ \\
\hline & UFFA & $25 \%$ & 1338 & $79.4 \%$ & 203 & $75.5 \%$ \\
\hline
\end{tabular}




\subsection{Calcium Chloride Resistance}

Calcium oxychloride (CAOXY) formation occurs primarily due to the reaction of calcium hydroxide $(\mathrm{CH})$, widely present in cement matrix, with calcium chloride, following the reaction:

$$
\mathrm{CaCl}_{2}+3 \mathrm{Ca}(\mathrm{OH})_{2}+12 \mathrm{H}_{2} \mathrm{O}=>3 \mathrm{Ca}(\mathrm{OH})_{2} \cdot \mathrm{CaCl}_{2} \cdot 12 \mathrm{H}_{2} \mathrm{O} \text {. }
$$

CAOXY is expansive and its formation can lead to damage when it occurs in a cementitious matrix, especially in presence of high Portland clinker content cements, such as CEM I or CEM II. Several mitigation strategies have been proposed to reduce the amount of CAOXY, including the use of supplementary cementitious materials that react with $\mathrm{CH}$ limiting the formation of calcium oxychloride $[39,40]$. Figure 17 shows the compressive strength over time of mortars stored in calcium chloride solution. The reference mortar, manufactured with CEM I 42.5R, already after 14 days in $\mathrm{CaCl}_{2}$ solution at $4{ }^{\circ} \mathrm{C}$ shows a strong damage (Figure 18) and a resulting reduction in mechanical performance. This indicates that Reaction [1] produces a high amount of CAOXY responsible for damaging the cement matrix. Specimens containing small amounts of fly ash or ultrafine fly ash (FA 5\% and UFFA 5\%) exhibit a similar behavior to the reference mortar, indicating that the presence of small amount of SCMs does not increase the resistance to calcium chloride attack. On the contrary, higher dosages of FA or UFFA react with greater amounts of $\mathrm{CH}$, strongly reducing the formation of CAOXY and the compressive strength loss over time. In detail, the high fineness of UFFA allows to attain a better behavior in $\mathrm{CaCl}_{2}$-rich environments. In fact, by substituting $25 \%$ of cement with ultrafine fly ash, it is possible to obtain a resistance to the formation of calcium oxychloride similar to that of mortars in which cement is replaced by $50 \%$ of FA. Finally, in manufacturing mortars containing $50 \%$ of ultrafine fly ash in place of cement, the CAOXY attack is strongly inhibited and the compressive strength slightly increases after 35 days in $30 \mathrm{wt} \% \mathrm{CaCl}_{2}$ solution at $4{ }^{\circ} \mathrm{C}$.

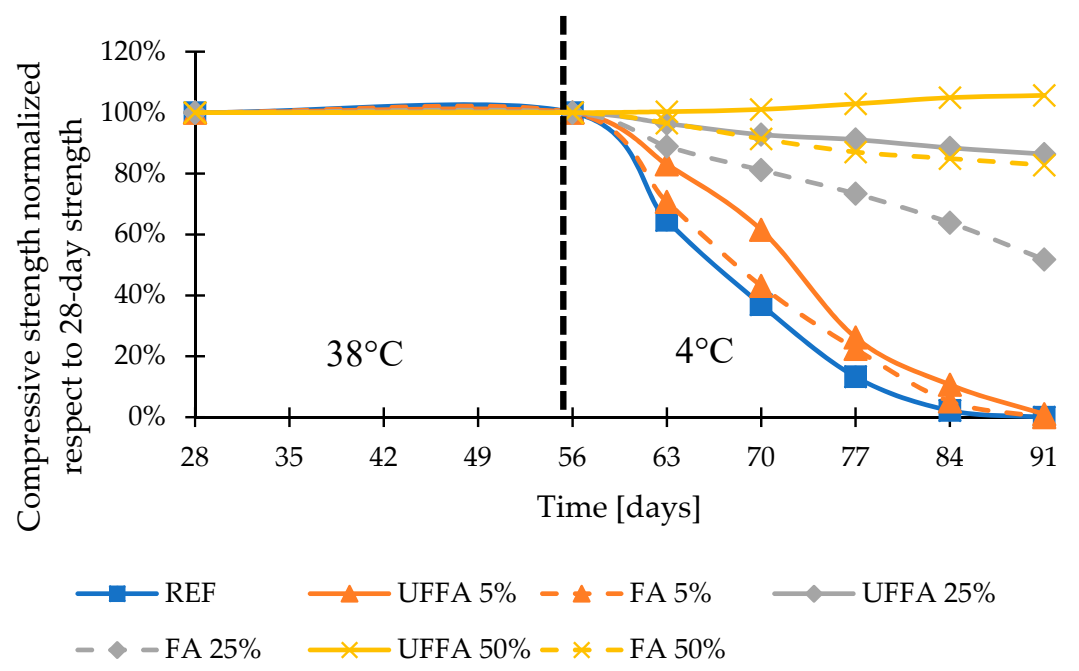

Figure 17. Compressive strength over time normalized respect to 28-day compressive strength of specimens stored in $30 \mathrm{wt} \% \mathrm{CaCl}_{2}$ solution.

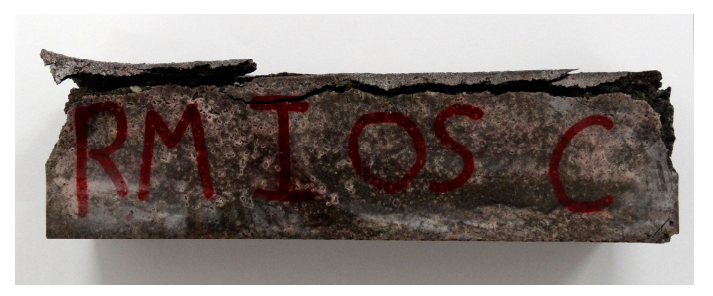

Figure 18. Specimen manufactured with CEM I $42.5 \mathrm{R}$ after 14 days in $30 \mathrm{wt} \% \mathrm{CaCl}_{2}$ solution at $4{ }^{\circ} \mathrm{C}$. 


\section{Conclusions}

In this paper, performances of mortars manufactured replacing different types of cement (more widely used in Italy: Portland, Portland limestone, slag, and pozzolanic) by low calcium siliceous (class F according to ASTM C618 [24] or type V according EN 197-1 [25] and EN 450-1 [26]) fly ash (FA) or ultrafine fly ash (UFFA was obtained by grinding FA) were evaluated.

- As a consequence of the grinding process, UFFA evidenced a reduction of average particle size (16.69 $\mu \mathrm{m}$ and $11.29 \mu \mathrm{m}$ is the D50 for FA and UFFA, respectively), and an increase in the specific surface area $\left(4500 \mathrm{~cm}^{2} / \mathrm{g}\right.$ and $6800 \mathrm{~cm}^{2} / \mathrm{g}$ for FA and UFFA, respectively).

- The partial replacement of Portland with the FA determines an increase in the workability of the mortars, at the same amount of water. Data shows a linear relationship between the increase in fluidity of the fresh mixtures along the percentage of FA replacing the cement, independently of the type of cement used. This behavior could be ascribed the spherical shape of FA particles. The grinding process, on the contrary, involves a general damage of particles, an increase in the number of irregular shaped particles, and a larger specific surface area responsible for a mitigation of the superplasticizing effect of UFFA compared to that shown by the (unground) fly ash.

- The strength pozzolanic activity index (K)-ratio of the compressive strength of mortar containing either UFFA or FA and the corresponding value of the reference mortar containing cement only, is generally higher for UFFA mortars compared to FA mixtures, regardless of the type of cement used and the percentage of replacement. Moreover, the mixtures containing up to $25 \%$ of UFFA exhibited higher compressive strength at 7,28 , and 84 days than reference mortars (cement only), independently of the type of cement used. On the other hand, compressive strength at 7 and 28 days of mortars with $35 \%$ of UFFA depends on the type of cement used. In fact, only mortars containing $35 \%$ of UFFA manufactured with CEM I $42.5 \mathrm{R}$ and CEM II/A-LL $42.5 \mathrm{R}$ show a $\mathrm{K}$-value higher than 1 . However, it can be observed that at 84 days, regardless of the type of cement used, the compressive strength of mortars containing 35\% of UFFA replacing cement is higher than that of mixtures manufactured exclusively with cement. Mortars manufactured with $50 \%$ of UFFA show values of K equal to 0.70 and 0.87 at 28 and 84 days, respectively.

- Replacement of Portland cement with FA or UFFA does not determine significant changes in hydraulic shrinkage. The shrinkage values of UFFA or FA based mortars are similar to those of cement-based mixtures.

- The GWP of the mortar manufactured with the UFFA is, at equal 28-day strength level, $35-40 \%$ lower with respect reference mortar (and about 20-35\% lower than the FA-based mortars having the same strength). Furthermore, the GER is reduced in UFFA-based mortars production of about 20-35\% vs. reference mortar (and \% lower than the FA-based mortars having the same strength).

- The use of ultrafine fly ash in partial substitution of cement for manufacturing mortars allows to attain a better behavior in $\mathrm{CaCl}_{2}$-rich environments in respect to that exhibit by unmilled fly-ash-based mortars or reference mixtures containing only cement.

Further experimentations are needed to investigate the durability issues of mortars manufactured with UFFA and FA, especially in sodium chloride- and sulphate-rich environments or in presence of alkali aggregates reaction and freeze/thaw cycles.

Author Contributions: All authors designed and managed the study and analyzed the experimental data. D.C. and E.C. performed the experiments and wrote the first draft of the manuscript. All authors read and approved the final manuscript.

Conflicts of Interest: The authors declare no conflict of interest.

\section{References}

1. Schneider, M.; Romer, M.; Tschudin, M.; Bolio, H. Sustainable cement production-present and future. Cem. Concr. Res. 2011, 41, 642-650. [CrossRef] 
2. Gartner, E.; Hirao, H. A review of alternative approaches to the reduction of $\mathrm{CO}_{2}$ emissions associated with the manufacture of the binder phase in concrete. Cem. Concr. Res. 2015, 78, 126-142. [CrossRef]

3. Mehta, P.K.; Walters, M. Road map to a sustainable concrete construction industry. Constr. Specif. 2008, 61, $45-57$.

4. Coppola, L.; Coffetti, D.; Lorenzi, S. Cement-Based Renders Manufactured with Phase-Change Materials: Applications and Feasibility. Adv. Mater. Sci. Eng. 2016, 2016. [CrossRef]

5. Loganathan, B.G.; Lam, P.K.S. Global Contamination Trends of Persistent Organic Chemicals; CRC Press: Boca Raton, FL, USA, 2012; 638p.

6. Kodavanti, P.R.S.; Senthil Kumar, K.; Loganathan, B.G. Organohalogen pollutants and human health. In The International Encyclopedia of Public Health; Academic Press: Oxford, UK, 2008; Volume 5, pp. 686-693.

7. Atmaca, A.; Kanoglu, M. Reducing energy consumption of a raw mill in cement industry. Energy 2012, 42, 261-269. [CrossRef]

8. Katsioti, M.; Tsakiridis, P.E.; Giannatos, P.; Tsibouki, Z.; Marinos, J. Characterization of various cement grinding aids and their impact on grindability and cement performance. Constr. Build. Mater. 2009, 23, 1954-1959. [CrossRef]

9. Coppola, L.; Kara, P.; Lorenzi, S. Concrete manufactured with crushed asphalt as partial replacement of natural aggregates. Mater. Constr. 2016, 66, 101. [CrossRef]

10. Coppola, L.; Buoso, A.; Coffetti, D.; Kara, P.; Lorenzi, S. Electric arc furnace granulated slag for sustainable concrete. Constr. Build. Mater. 2016, 123, 115-119. [CrossRef]

11. Coppola, L.; Lorenzi, S.; Buoso, A. Electric arc furnace granulated slag as a partial replacement of natural aggregates for concrete production. In Proceedings of the 2nd International Conference on Sustainable Construction Materials and Technologies, Ancona, Italy, 28-30 June 2010.

12. Coppola, L.; Cerulli, T.; Salvioni, D. Sustainable development and durability of self-compacting concretes. In Proceedings of the 11th International Conference on Fracture, Turin, Italy, 20-25 March 2005.

13. Ahmaruzzaman, M. A review on the utilization of fly ash. Prog. Energy Combust. Sci. 2010, 36, 327-363. [CrossRef]

14. Yao, Z.T.; Ji, X.S.; Sarker, P.K.; Tang, J.H.; Ge, L.Q.; Xia, M.S.; Xi, Y.Q. A comprehensive review on the applications of coal fly ash. Earth-Sci. Rev. 2015, 141, 105-121. [CrossRef]

15. González, A.; Navia, R.; Moreno, N. Fly ashes from coal and petroleum coke combustion: Current and innovative potential applications. Waste Manag. Res. 2009, 27, 976-987. [CrossRef] [PubMed]

16. Bilodeau, A.; Mohan Malhotra, V. High-volume fly ash system: Concrete solution for sustainable development. ACI Struct. J. 2000, 97, 41-48.

17. Bouzoubaâ, N.L. Self Compacting Concrete Incorporating High-Volumes of Class F Fly Ash: Preliminary Results. Cem. Concr. Res. 2001, 31, 413-420. [CrossRef]

18. Siddique, R. Performance characteristics of high-volume Class F fly ash concrete. Cem. Concr. Res. 2004, 34, 487-493. [CrossRef]

19. Ponikiewski, T.; Gołaszewski, J. The influence of high-calcium fly ash on the properties of fresh and hardened self-compacting concrete and high performance self-compacting concrete. J. Clean. Prod. 2014, 72, $212-221$. [CrossRef]

20. Ponikiewski, T.; Gołaszewski, J. The effect of high-calcium fly ash on selected properties of self-compacting concrete. Arch. Civ. Mech. Eng. 2014, 14, 455-465. [CrossRef]

21. Ponikiewski, T.; Gołaszewski, J. The Rheological and Mechanical Properties of High-performance Self-compacting Concrete with High-calcium Fly Ash. Procedia Eng. 2013, 65, 33-38. [CrossRef]

22. Jones, M.R.; McCarthy, A.; Booth, A.P.P.G. Characteristics of the ultrafine component of fly ash. Fuel 2006, 85, 2250-2259. [CrossRef]

23. Yazici, S.; Arel, H.S. Effects of fly ash fineness on the mechanical properties of concrete. Sadhana 2012, 37, 389-403. [CrossRef]

24. ASTM International. ASTM C618-Standard Specification for Coal Fly Ash and Raw or Calcined Natural Pozzolan for Use in Concrete; ASTM International: West Conshohocken, PA, USA, 2008.

25. British Standards Institute Staff, British Standards Institution. Cement. Composition, Specifications and Conformity Criteria for Common Cements; EN 197-1; BSI: London, UK, 2004.

26. European Committee for Standardization. Fly Ash for Concrete-Part 1: Definition, Specifications and Conformity Criteria; EN 450-1; European Committee for Standardization: Brussels, Belgium, 2012. 
27. Supit, S.W.M.; Shaikh, F.U.A.; Sarker, P.K. Effect of ultrafine fly ash on mechanical properties of high volume fly ash mortar. Constr. Build. Mater. 2014, 51, 278-286. [CrossRef]

28. Chindaprasirt, P.; Jaturapitakkul, C.; Sinsiri, T. Effect of fly ash fineness on compressive strength and pore size of blended cement paste. Cem. Concr. Compos. 2005, 27, 425-458. [CrossRef]

29. Shaikh, F.U.A.; Supit, S.W.M. Compressive strength and durability properties of high volume fly ash (HVFA) concretes containing ultrafine fly ash (UFFA). Constr. Build. Mater. 2015, 82, 192-205. [CrossRef]

30. Chindaprasirt, P.; Homwuttiwong, S.; Sirivivatnanon, V. Influence of fly ash fineness on strength, drying shrinkage and sulfate resistance of blended cement mortar. Cem. Concr. Res. 2004, 34, 1087-1092. [CrossRef]

31. Sinsiri, T.; Teeramit, P.; Jaturapitakkul, C.; Kiattikomol, K. Effect of finenesses of fly ash on expansion of mortars in magnesium sulfate. Sci. Asia 2006, 32, 63-69. [CrossRef]

32. Chen, C.; Habert, G.; Bouzidi, Y.; Jullien, A. Environmental impact of cement production: Detail of the different processes and cement plant variability evaluation. J. Clean. Prod. 2010, 18, 478-485. [CrossRef]

33. Huntzinger, D.N.; Eatmon, T.D. A life-Cycle assessment of Portland cement manufacturing: Comparing the traditional process with alternative technologies. J. Clean. Prod. 2009, 17, 668-675. [CrossRef]

34. British Standards Institute Staff, British Standards Institution. Methods of Test for Mortar for Masonry. Determination of Consistence of Fresh Mortar (by Flow Table); EN 1015-3; British Standards Institution: London, UK, 1999.

35. British Standards Institute Staff, British Standards Institution. Methods of Test for Mortar for Masonry. Determination of Bulk Density of Fresh Mortar; EN 1015-6; British Standards Institution: London, UK, 1999.

36. British Standards Institute Staff, British Standards Institution. Methods of Test for Mortar for Masonry. Determination of Flexural and Compressive Strength of Hardened Mortar; EN 1015-11; British Standards Institution: London, UK, 1999.

37. British Standards Institute Staff, British Standards Institution. Concrete. Specification, Performance, Production and Conformity; EN 206-1; British Standards Institution: London, UK, 2013.

38. Metrology and Testing Czech Office for Standards. Products and Systems for the Protection and Repair of Concrete Structures. Test Methods. Determination of Shrinkage and Expansion; EN 12617-4; British Standards Institution: London, UK, 2002.

39. Suraneni, P.; Azad, V.J.; Isgor, B.O.; Weiss, W.J. Calcium oxychloride formation in pastes containing supplementary cementitious materials: Thoughts on the role of cement and supplementary cementitious materials reactivity. RILEM Tech. Lett. 2016, 1, 24. [CrossRef]

40. Farnam, Y.; Washington, T.; Weiss, J. The Influence of Calcium Chloride Salt Solution on the Transport Properties of Cementitious Materials. Adv. Civ. Eng. 2015, 2015, 1-15. [CrossRef] 